Unters. Schwz. Nationalpark., 5 : 215-377. -13) Willmann, C. (1930): Neue Oribatiden aus Guatemala. Zool. Anzg., 88 : 239-246. -14) Willmann, C. (1931): Moosmilben oder Oribatiden (Oribatei, in : Tierw. Deutschl., 22:79-200. -15) Willmann,
C. (1935): Die Milbenfauna, in : Jaus, I. : Faunistisch-ökologische Studien im Annigergebiet, mit besonderer Berücksichtigung der xerothermen Formen. Zool. Jahrb. Abt. f. Syst., Ökol. u. Geogr. der Tiere, 66 : 331-344.

\title{
日本産ノミバエ科に関する研究
}

\author{
第 1 報 1 末記録種在含先ノミバェ 6 種について
}

\section{Studies on phorid flies (Phoridae, Diptera) in Japan \\ Part I. Key to subfamilies and important genera of Phoridae, and descriptions of six species belonging to five genera}

\author{
金子清 俊* 加 納 六 郎* 岡崎 常太 郎* \\ Kiyotoshi Kaneko, Rokuro Kano and Tsunetaro Okazaki
}

\section{緒言}

ノミバェ科に関する最も古い記録は，1796 年に Latreille が Phora (属) として記載したものである。その 後今日までに多くの研究者によつて世界で約 1,600 種が 報告されている，これらのうち本邦産のノミバェは1938 年以来 Schmitz, H. 㧍よび Brues, C. T. らによつて 8 属 18 種が紹介されているが，わが国からの報告は極め て少ない. 1915, 6 年に松村が Conicera japonica（ク ロノミバェ), Phora apicalis (キイロノミバエ)の 2 種 を発表したのが本邦からの最初の記載で，次で木下 (1918) が東大，伝染病研究所構内に放置されたモルモッ トの屍体走行していた無翅!ミバェをPuliciphora tokyoensis こして発表した。また素木は日本昆虫図鑑 (1932)にPhora egregia（キゴシノミバェ）をあげー いるが， Schmitz (1949) はこ在 Diploneura（Tristoechia) bifasciata Walker, 1860 の synonym とした いる. その後佳々木（1935） は松茸に寄生するもの在松 茸バエ，すなわち Aphiochaeta matsutakei 上して報告 している.

ノミバエ科に属するもの微小な八工類で, 幼虫は植 物の腐触したものまたは動物の㡾体などに発生し, 時上

* 東京医科歯科大学医動物学教空

Department of Medical Zoology, School of Medi. cine, Tokyo Medical and Dental University
して昆虫，カタッムリおよび白蟻の巣などに寄生する。 今日まで日本ではノミバェ科の八エについてはあまり注 意されていなかつたが，最近これらの八エが食品類に混 人したり，偶発性八エ症の例が本邦各地でしばしば見出 されるなど衛生学的にも重要視されるようになつた。そ こで著者らは Schmitzの分類考参考にして日本産ノミ バエ科の重科㧍よ゙重要属の検索表を作製し：合わせて 普通種 5 種ならびに 1 末記録種を記載する。

\section{ノミバエ科の特徽}

本科の八エは甚だ小形で, 胸背部は円く凸出してあた かも佝僂の如き形をなし，極めて活潑に飛翔または歩走 する. 従つて欧米では Humpbacked flies, Buckelfiiegen などと呼ばれている。

頭部は小さく前㣪に扁平で，額は一般に特有な棘毛を 有する，触角は 3 節からなり第 3 節は大形で，先端また は亜先端部から触角刺毛（端刺）を生ずる. 脚注比較的 大きく, 脛節の剛毛の有無および数は, 属, 種の特徵よ して重要である，翅は通常存在するが，中には痕跡的な もの，全くないもの，あるいは雌のみ無翅のものなどが ある，翅脈は双翅目中の他のもの上著しく異なり，前縁 脈, 第 1 脈 $\left(r_{1}\right)$, 第 2 脈 $\left(r_{4}\right)$, および第 3 脈 $\left(r_{5}\right)$ が太 く，あこは細い縦脈であり横脈をもたない（図1） 


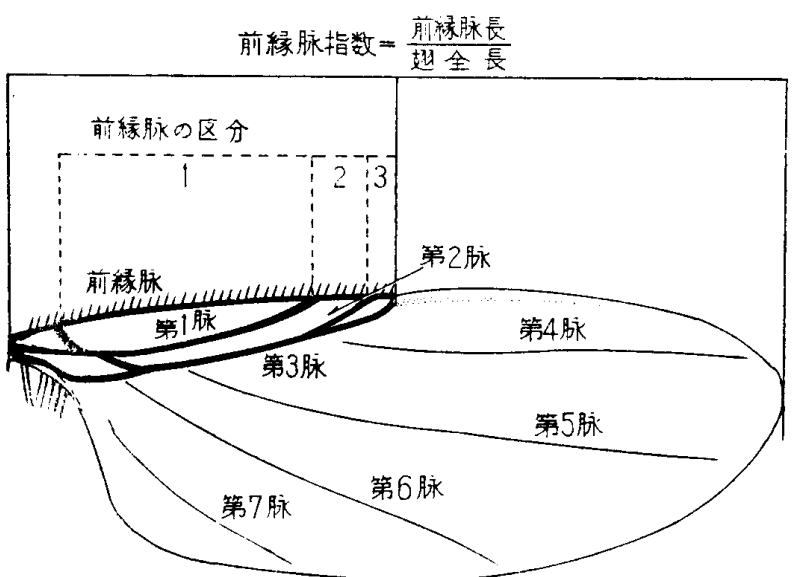

因 1 ノミバェ科の趐脈

第 1 脈 $\left(r_{1}\right)$; 第 2 脈 $\left(r_{4}\right)$; 第 3 脈 $\left(r_{5}\right)$; 第 4 脈 $\left(m_{1}\right)$; 第 5 脈 $\left(m_{2}\right)$; 第 6 脈 $\left(m_{4}\right)$; 第 7 脈 (an)

\section{分類学上の地位}

双翅目 Diptera Linné, 1758

環縫亜目 Cyclorrhapha Brauer, 1880

無額囊群 Aschiza Becker, 1882

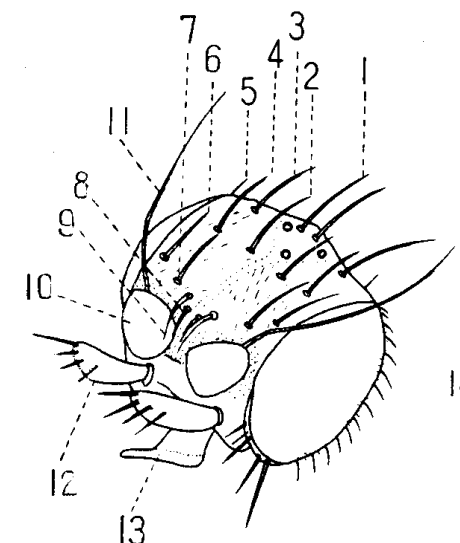

A (Metopininoe)
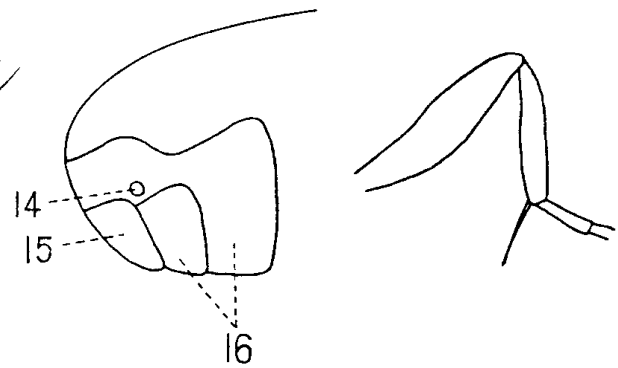

B (Phorinae)
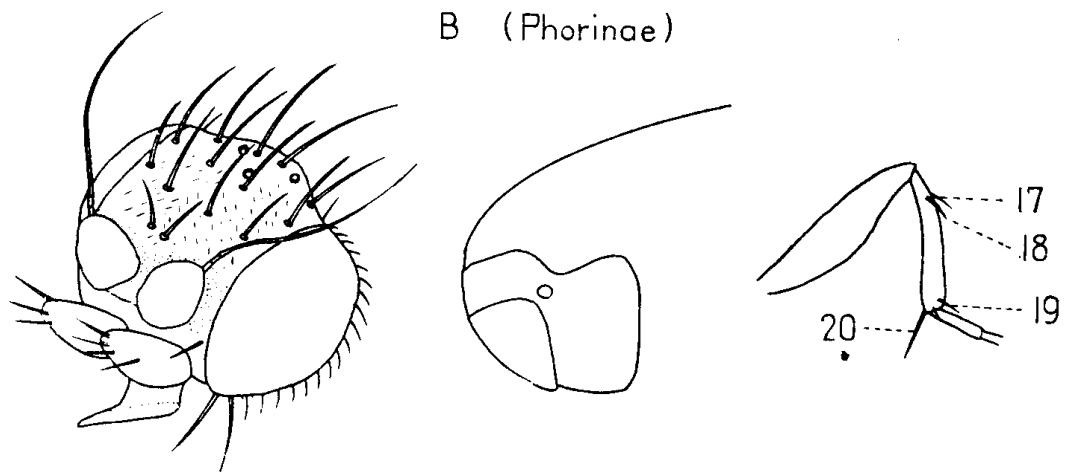

図 2 Phorinae, Metopininae の頋部，胸部和よび第 2 脚脛節

1. 单眼棘毛；2. 单眼前棘毛；3. 頭頂䊂毛；4. 第 3 眼縁棘毛；

5. 後頭棘毛； 6 . 第 2 眼縁棘毛； 7 . 第 1 眼緑棘毛; ;8. 第 2 触角上棘毛；9．第 1 触角上棘毛；10. 触角第 3 節；11. 触角 刺毛; 12. 触鬚; 13. 吻; 14. 前胸気門; 15. 前胸側板; 16. 中胸側板；17. 上前側剛毛；18. 前背剛毛；19. 下前背 剛毛 (严先端前背剛毛)；20. 終剛毛
ノミバエ科 Phoridae Latreille, 1796

ノミバェ亜科 Phorinae Bezzi, 1916

トゲナシアシノミバエ亜科 Metopininae Brues, 1932

アリノミバェ带科 Aenigmatiinae Enderlein, 1908

\section{ノミパエ科の亞科の検索表}

1.中胸側板は雨側に張り出しているために体は幅広 く，前胸気門は背面から見られる。横から見た場合は中 胸側板が前方にのびているため前胸側板の後縁は見えに くい．また前胸気門は中胸側板上縁の延長線より上にあ 万. $\cdots \ldots \ldots \ldots \ldots \ldots \ldots \ldots \ldots$ Aenigmatiinae

一中胸側板は両側に張り出すことなく，前胸気門は 背面から見えない，横から見た場合は，前胸側板も気門 も明瞭に認められる。また前胸気門は中胸側板上縁の延 長線より下にある，……………… 2

2. 脛節には独立剛毛を有する，少なくとも第 2 脚の 脛節には，その中央またはそれよりやや上部に 1 対の剛 毛を有する。ささらに旧北区産のものでは雌雄共に正常な 翅を有する，額は後半部のみならず，前方まで微毛で覆 われている．触角上棘毛は斜上方に彎曲 している．中胸側板は常に 1 個の板であ つて，2 個に区切られていない，…. .............

一脛節には独立剛毛を有せず，縁に 氈毛列を有するかまたはそれをも欠く. 時に第 3 脚脛節の後背部にかなり良く発 達した氈毛列を生ずることがある，触角 上棘毛は斜下方に彎曲している．中胸側 板は常に 2 個に区切られている。 ..... ............. Metopininae (図 2 A)

\section{日本産ノミバエ要科の既知属の 検索表}

1. 第 3 翅脈は分枝している $\left(\mathrm{r}_{4}\right.$ と $\mathrm{r}_{5}$ に分かれる）， $\mathrm{r}_{4}$ は稀に非常に弱く不明 瞭な場台もある。…………2

一第 3 翅脈は分枝しない。すなわち $r_{4}$ を完全に久く. $\cdots \cdots \cdots \cdots \cdots \cdots$

2. 中胸側板には全く毛を久く.・3

一中胸側板の上半部に若干の 毛を有 するか，または時として長い独立剛毛が ある。 ….............. 5

3. 第 3 脚脛節の背側は溝を欠き”— 
様な壇毛を有する。(独立剛毛が見られることもある)・ ..............................

一第 3 脚脛節の背側は細い溝によつて互いに分かれ た $2 \sim 3$ の剛毛列がある. ……... Diploneura

4. 第 3 翅脈 $\left(r_{5}\right)$ は $r_{4}$ と $r_{5}$ との分枝点迄 $20 \sim 45$ 本の小棘毛列がある。........................

一第 3 翅脈は小棘毛在欠く. ……Spiniphora

5. 第 3 脚脛節の背側にはただ 1 列の 兓毛列を有す る. 第 2 翅脈 $\left(r_{4}\right)$ は明瞭であるが, $r_{4}$ と $r_{5}$ との間の室 は狭い，雌では長い刺吻を有する．…… Diploneura

一第 3 脚脛節の背側は 2 列の氈毛列を有する． $\mathrm{r}_{4}$ は 弱く繊細で色がうすい，雌の吻は太い。. Borophaga

6. 雄の額は細長く狭い. 雄雌共に額の中央に溝があ る、腹節はビロードがかつた黒色である，…Phora

一額の中央には溝がなく, 額は特に狭いほどではな w. $\cdots \cdots \cdots \cdots \cdots \cdots \cdots \cdots \cdots \cdots \cdots \cdots \cdots$

7. 第 3 脚脛節背側の稜には先端部のもの以外にも独 立剛毛を有する。頭頂板 (単眼 3 角) は普通. $\cdots \cdot 8$

一第 3 脚脛節背側の稜には先端部に少数の剛毛があ るにすぎない。しかし稜をはずれた部分に独立剛毛があ る. 頭頂板 (単眼 3 角) は幅広く前方が 3 つの波型に突 出している. ……................ Stichillus

8. 触角刺毛注触角第 3 節の先端から生ずる. 雄の触 角第 3 節は先端が細まり長く延びている. 第 3 脚脛節に は 3 本の発達した剛毛がある.(基部に近く 1 対とほぼ中 央に 1 本)，……………………

一触角刺毛は触角第 3 節の背面亜先端部から生ず る. 第 3 脚脛節は多数の風毛を有する。すなわち背側に 3 本, 前面に 2 本, 腹面に 1 本である. 胸背は 4 対の正 中剛毛を有する. 本種は日本からのみ知られ, 雄は未だ 不明. Kuenburgia

\section{日本産ノミバエ亜科の主要属の概説}

1. Genus Diploneura Lioy, 1864

本属は Phorinae のうちで種類が一番多く, 約 100 種 が知られている。この属は次の 3 亜属に分かれる.

A. Subgenus Diploneura Lioy, 1864

Phorynchus Brunetti, 1912

Pentagynoplax Enderlein, 1924

雄の腹節は普通で単純. 第 3 脚脛節は背側に溝をはさ んで 2 列の長毛列を有する，第 4 脈 $\left(\mathrm{m}_{1}\right)$ は $\mathrm{S}$ 字状を呈 し基部が凹彎し，先端部をたは先端 $1 / 3$ のところから凸
彎している。

B. Subgenus Tristoechia Schmitz, 1927

雄の腿節は普通で単純. 第 3 脚脛節は雌雄共に 3 列の 波型の長い毛列を有し，背面後部で狭くなつている， m 脈は完全に真值である。

C. Subgenus Dohrniphora Dahl, 1898

Pronomiophora Enderlein. 1912

Crepidopachys Enderlein. 1912

第 3 脚腿節の基部腹面に大小異なつた数本の黒い感覚 棘を有する。またその近くに皿状の山部がある。第 3 脚 脛節背側はただ 1 毛列を有するのみ， $\mathrm{m}_{1}$ 脈は常に前方 に向つて凹彎している。

2. Genus Aneurina Lioy, 1864

Chaetoneura Malloch, 1909

Stenophora Malloch, 1909

Chaetoneurophora Malloch, 1912

Pseudostenophora Malloch, 1912

Trisometopia Enderlein, 1924

小楯板は 4 剛毛を有し，中胸側板には微毛なし．第 6 背板は甚だ長く，雌の場合は特に長く後縁が狭くなり揳 型を呈する。第 1 脚の脛節には中央近くに 1 本の背側毛 を有し，第 2 脚脛節には通常 1 対の毛の近くに亜前縁毛 を有する。前縁脈長は常に翅長の半分より長い。前縁脈 の区分の長さは 1 が $2+3$ よりわずかに短かい. 第 3 脈 は $\mathrm{r}_{4}$ 上 $\mathrm{r}_{5}$ の分岐点迄 $20 \sim 45$ 本の黒色の小棘毛を有す る. $\mathrm{m}_{1}$ 脈の基部が $\mathrm{S}$ 字状に彎曲している.

3. Genus Stichillus Enderlein, 1924

Tressinus Schmitz, 1924

Tristichothyrsus, Enderlein, 1936

第 3 翅脈汾分枝していない，すなわち $\mathrm{r}_{4}$ を欠く。前 縁脈の区分は 1 と2とが同長かまたは 1 が 2 の 1.5 倍ま での長さである。第2脚脛節には 1 対の成毛を有し，第 3 脚脛節も稜には剛毛がないが，側面に独立剛毛を有 する. 特に本属の特徵は, 頭頂板 (単眼 3 角) の幅が広 く, 前下方に向かつて 3 つの波型に隆起していることで ある.

4. Genus Conicera Meigen, 1830

本属はこれまでに約 30 種が知られていて，3亜属に分 けられる。これら 3 亜属の特徵を次に示寸.

A. Subgenus Conicera Meigen, 1830

第 6 翅脈 $\left(\mathrm{m}_{4}\right)$ 乙第 7 翅脈 (an) 注雌雄共に翅の縁ま で達する．第 2 脚腿節は雌雄共に付属物なく普通. 雄の 触角上棘毛および雌雄の第 3 眼縁毛は欠如する. 雄の鉄 子は両方が離れていて，形は筆状である。

B. Subgenus Hypocerina Malloch, 1915

第 6 翅脈と第 7 翅脈は雌雄共に翅の縁に達寸る. 第 2 脚腿節には付属物なく普通. 


\section{繁 生動 物 1961 年 Vol. 12 No. 4}

右の鋏子の内縁に広く突出した板，または栓状の突起 物交有する。

C. Subgenus Tritoconicera Schmitz, 1952

第 6 翅脈と第 7 翅脈は雄では翅の縁まで達しない。右 の鋏子の付近に広く突出した付属物はない，第 2 脚腿節 は脛節に近い部分に感覚器と思われる小畐があつて，そ こから管棘を生ずる。1 対の触角上棘毛は雄雌共に非常 に短加、

\section{日本産トゲナシアシノミバェ重科の 既知属の検索並びにその概説}

本亜科は現在までに約 93 属，1,150 種が知られている が，日本からは Megaselia Rondani, 1856 および Woodiphora Schmitz, 1925 の 2 属が知られているにすぎな い. 著者らは今日までに Woodiphora 属のものを採集 していないこの 2 属の区别点は下記の如くである.

Megaselia ……第 3 脚脛節背面に汢 1 列の氈毛列があ り，後背面には氈毛列にそつてほ上んど常に 1 列の毛列 がある。その毛は種により細太多少がみられる。

Woodiphora.... 第 3 脚脛節の背面は単に微毛がある のみで Megaselia の如き毛列はない。

1. Megaselia Rondani, 1856

本属は全世界に分布し Phoridae の1/3 ないしそれ以 上が Megaselia に属し現在まで 710 種が知られている.

頭部の触角上棘毛は 2 対あつて前方に下曲している. 触角の第 3 節は雌雄共に丸い，中胸側板には毛を有する ものと無いものがあり，この毛の有無は亜属の特徴とな る. 雌雄共に正常な翅を有し，第 3 翅脈注完全に二分岐 する．第 3 脚腿節は通常腹側の基半部に長短不同の毛を 有する. 第 2 脚脛節には第 3 脚脛節のものより長くて丈 夫な主棘が腹側端にある. 本属は次の 2 带属に分かれ 万。

A Subgenus Aphiochaeta Brues, 1904

Byrsophrys Enderlein, 1912

Paraphiochaeta Malloch, 1914

Mallochina Schmitz, 1918

Pogonopleura Enderlein, 1924

Stirocnemia Enderlein, 1927

特徵は中胸側板上に毛老有する.

B. Subgenus Megaselia Rondani, 1856

Trisometopia Lioy, 1864

Obelosia Lioy, 1864

Lioyella Enderlein, 1924

Heterophora Borgmeier, 1923

特徴は中胸側板上に毛がない。

2. Genus Woodiphora Schmitz, 1925
暗色の小型種である．額は中央の溝にそつてやや著明 な微毛を有する。触角上棘毛は斜上方に管曲する。複眼 には微毛を有する。触角第 3 節は丸く, 触角刺毛注悡 先端部から生じ，長い微毛を有する。雄雌の触鬚は長く 雄では幅が広く平坦でほと儿ど無毛である。雌は多少剛 毛を有する。雌の吻はキチン化が弱く，5対内外の偽気 管を有する，胸部は正常な毛を有し，背中剛毛は 1 対， 小楯板剛毛は 4 対，前胸側板の後縁は毛を有する。中胸 側板は無毛. 腹部は正常. 背板上の毛は弱い。第 6 背板 の前縁中央部に小腺蓋がある。しかしその蓋注開かない. 第 3 脚脛節には 2 列の亶毛毛列があり，そのうちの 1 列は 他列の半分の長さである，翅の前縁脈は長い，前縁脈緎 毛は常に短かい，前縁脈の区分は種特有であるが，雌雄 でしばしば異なる。第 2 脈 $\left(\mathrm{r}_{4}\right)$ は前縁脈に垂直である。

\section{日本産ノミバエ科の 6 種の概説}

1. Diploneura (Dohrniphora) cornuta

(Bigot, 1857)（図 3)

コシアキノミバェ（新称）

\author{
Phora navigans Frauenfeld, 1867 \\ Phora cleghorni Bigot, 1890 \\ Phora chloeogastra Becker, 1901 \\ Phora venusta Coquillett, 1895 \\ Phora divaricata Aldrich, 1896 \\ Phora mordax Brues, 1911 \\ Dohrniphora bequaerti Schmitz, 1914
}

本種は全世界に分布し熱帯, 覀熱帯に極めて多く, 本 邦でも各地で普通に認められる。

雄 : 額は長さより幅がいくらか広く，黑色. 触角前棘 毛は良く発達し，上彎している。眼縁下方に良く発達し た煩剛毛があり，その後方に互いに離れた2剛毛があ る。触角の第 3 節は幅より長さがわずかに長い，触角㔀 毛注普通. 触髣憕色で下側の稜に黑色の剛毛を有す る. 剛毛は長さが長短不同で通常 5 本. 吻は短かく黄 色. 胸背部は黒褐色. 後縁には翅後剛毛, 背中剛毛があ り，往々黄色い明るい線が見られる。中胸側板の上半部 に微毛を有する，小楯板は短かく，幅は長さの約 4 倍. 側板は二色性で腹胸側板，下側板，趐側板は黒色を帯び た灰色で，その境は鮮明. 腹部は黄色. 第 2 ，第 6 背板 は長い，第 1 背板は黄褐色. 後縁は楔形の暗い横線があ る. 第 2 背板は前半が黄色で後半が黒色である. 黄色部 の後縁は一直線であるが中央部がわずかに出する。第 3 背板から第 5 背板迄は黒色で各前縁の中央に非常に小 さい三角形の黄色い部分がある．第 6 背板は前半が黄色 い部分でしめられている. 第 1 脚脛節は前背部に $3 \sim 6$ 本の剛毛を有寸る. 第 2 脚脛節に注通常基部 $1 / 5$ の部分 

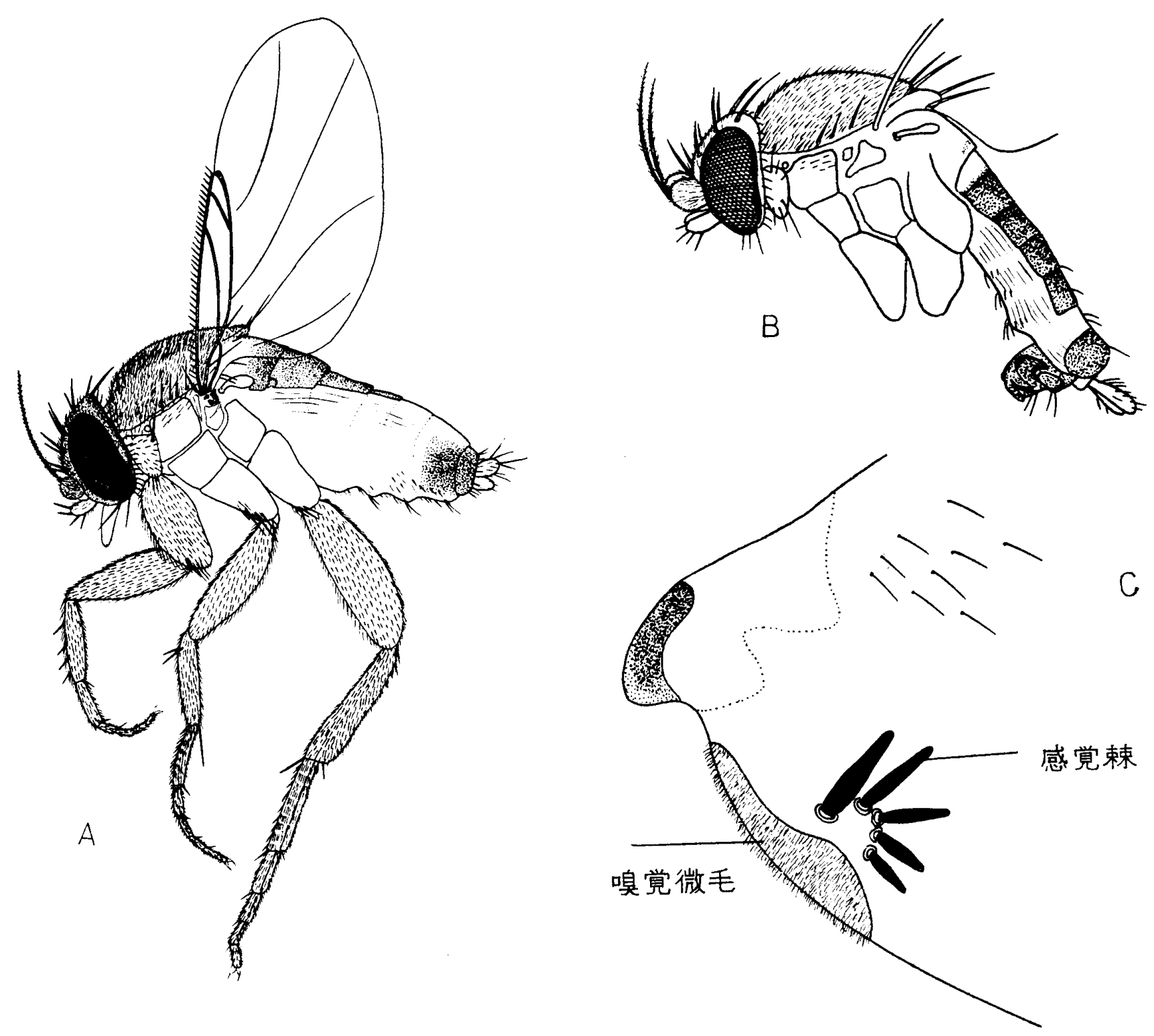

図 3 Diploneura (Dohrniphora) cornuta Bigot

A. 雌; B. 雄; C. 第 3 脚腿節

に 1 対の剛毛を有する. 第 3 脚腿節の長さは幅の 2.5 倍 であり，基部腹側に黒色で先端の鈍い大小不同の感覚棘 が 5 本以上ある。（図 3 C）第 3 脚脛節 は独立剛毛を有 せず，同後部背面に弱い繊毛を有するにすぎない，翅は 特に短かく，やや黄色味を帯びている。前縁脈指数は $0.49 \sim 0.52$. 前縁脈各部の比は不定であるが1は $2+3$ の約 3 倍（模式標本では20:5:2）。第 4 脈は第 2 , 第

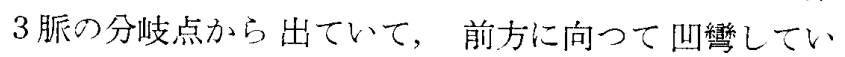
る。第 7 脈は非常に弱い. 平均棍汢黄色. 体長 $1.9 \sim 2.3$ $\mathrm{mm}$.

䧳：触角は雄より小さい，色は明るく丸味を帯びてい る。触角刺毛泣長い。触䰅は橙色で長さと幅の関係は $17: 9$ または $11: 6$ である。吻は橙色で偽気管は 4 対で 大きい(雄は 5 対で小さい). 胸部は雄と同様. 腹部は
雄より明るい，第 1 背板は雄と同じ，第 2 背板は大きく 暗色かまたは前部が黄褐色. 第 3 第 4 背板の黒褐色部は 次第に幅が狭くなつている. 第 5 背板より後は黒褐色に キチン化した部分はなく一様に暗色を呈する．第 3 脚腿 節は長さが幅の 3 倍, 基部腹面には感覚棘なし. 翅は長 さが幅の約 2 倍, 前縁脈指数は雄より大きく 0.54 . 体長 は $1.5 \sim 2.4 \mathrm{~mm}$.

\section{Diploneura (Diploneura) peregrina}

(Wiedemann, 1830) (図 4)

$$
\text { オオアカノミバェ（新称） }
$$

Phora sinensis Schiner, 1868

Phora conventa Brues, 1911

雄 : 頭部は黄色. 額は方形で長さより幅がいくらか広 

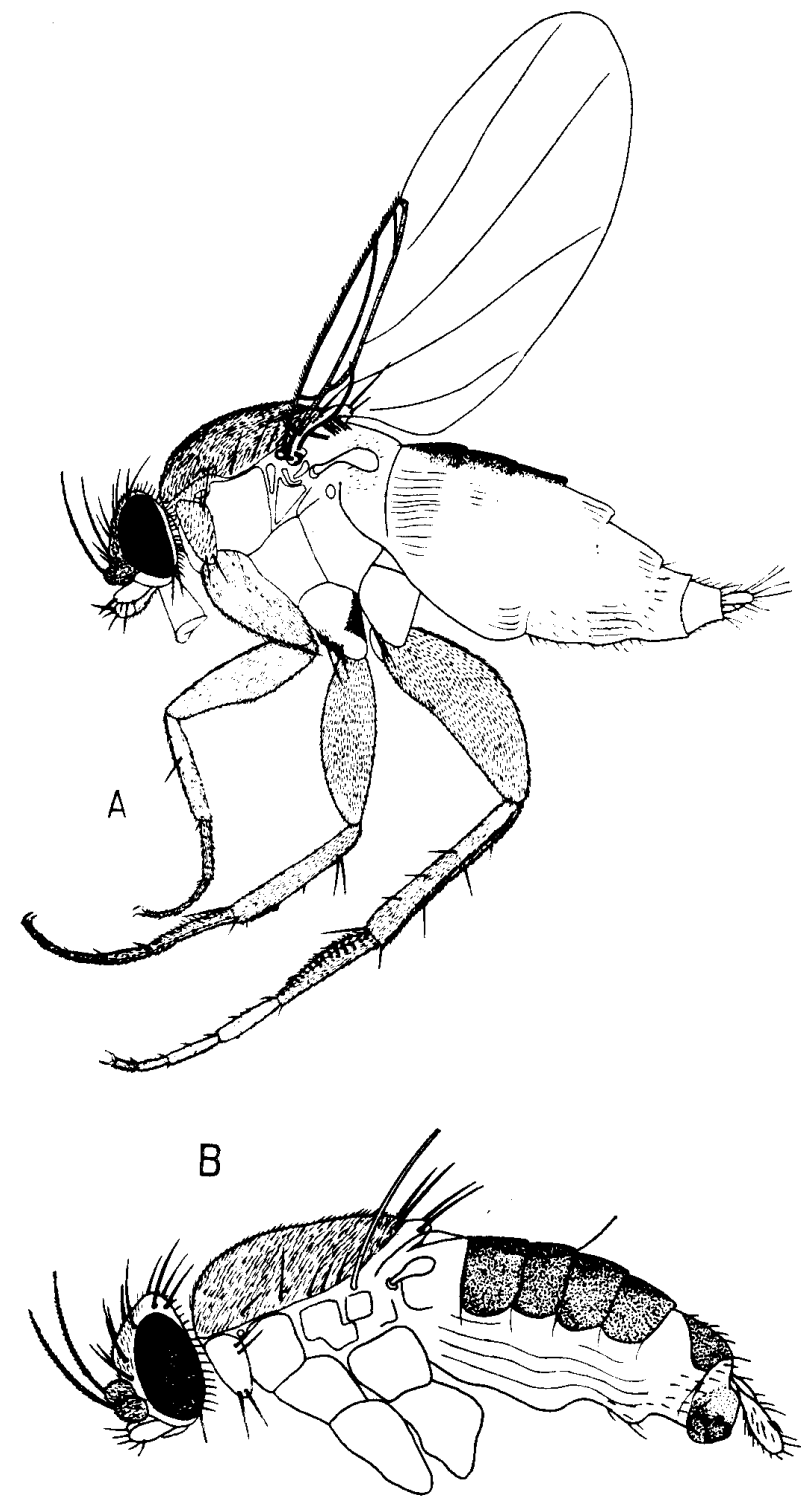

図 4 Diploncura (Diploneura) peregrina Wiedemann
A. 雌; B. 雄

い，触角は小さく橙色. 先端は時として弱い暗色. 触角 刺毛は短かく多々の微毛を有する. 触鬚は黄色. 側面に 太い $6 \sim 8$ 本の剛毛があり, 先端剛毛は他より長い. 胸 は黄赤色. 2 対の背中剛毛があり，それらは細くて長 い. 小楯板は黄赤色で 2 対の用毛を有し, 内側の 1 対注 外側の1対より短かい，腹部は黄赤色で第 1 背板は後縁 が真淔である。第 2 から第 6 背板は後縁に帯黄赤色部が 拡がつている，第 1 脚脛節は中央より少し上部に前面剛 毛を有する、第 2 脚脛節には中央に 1 本と基部に近く 1 対の剛毛を有する。第 3 脚脛節は 3 本の前背剛毛と 3 4 本の間隔が不同の前腹剛毛を有寸る。翅は黄色味が強 く, 長さは幅の 2.5 倍. 前縁脈の各区分の比は（30:9: 5)であり 1 は2+3よりはるかに長い。前縁脈緎毛は非 常に短汃、平均棍は黄色. 体長は $3 \mathrm{~mm}$ 内外.

雌 : 大体雄上同じであるが背板が非常に異なる。黒褐
色のキチン板は第 1 第 4 までで，第 5 より後は黒褐色 の板を有せず，単に暗色膜様である，吻は太い，体長は $4 \sim 4.5 \mathrm{~mm}$.

3. Aneurina unispinosa (Zetterstedt, 1860) (図 5)

$$
\text { ウスグロノミバェ (新称) }
$$

Phora fennica Becker, 1901

本種はヨーロッパに産しわが国からの報告はこれが最 初である. 北海道河東郡棣平で1961年 7 月に加納が採集 したもので雄は得られなかつた。

雄 : 額は長さより幅が広く黒色. 触角第 3 節は大きく 黒色. 稀には赤褐色のものも市る.触角刺毛は微毛を有 し黄褐色. 触弉は細長く，黄色またはオレンジ色で 8 10本の短剛毛を有する，胸は黒色，側板も黒色かまたは 暗褐色. 中胸側板には毛がない，腹部は黒色. 第 1 ，第 2 背板は大きく長い. 腹部後方は沢山の微毛を有する. 小楯板剛毛は 4 本. 第 1 脚脛節背面中央に 1 本, 第 2 脚 には背面基部近くに 1 対と亜先端前面剛毛がある．第 3 脚には中央よりやや基部に 1 本および亜先端前面剛毛を 有する。翅はわずかに黄色味を帯びた扊色で薷つてい

図 5 Aneurina unispinosa Zetterstedt, 雌 （第 3 翅脈の小棘毛は翅の上面に列生する）

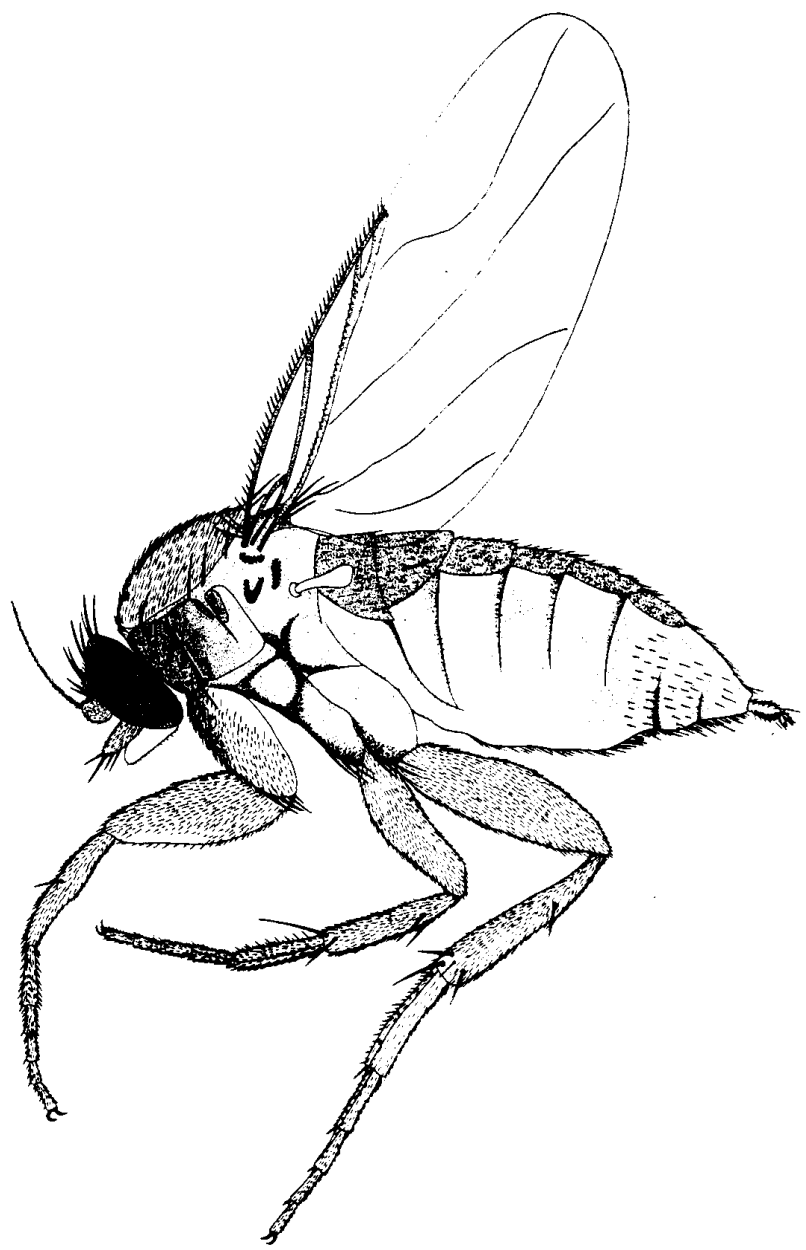


る. その基部は特に黄色い，前縁脈指数は大体 0.6 . 㵶 毛海かい. 前縁脈の各区分の比注 $20: 11: 5$ であり, 1 は $2+3$ より長い. 第 3 脈は分岐点まで約 36 本の黒色 小棘毛を有する．第 4 脈 $\left(\mathrm{m}_{1}\right)$ 注 $\mathrm{S}$ 字状に屈曲している。 平均棍は黄白色. 体長 $2 \sim 3 \mathrm{~mm}$.

雌: 大体雄と同様. 触角注小形。触髹注幅が広い，背 板は第 1 ，第 2 が広く大きい，翅は雄より少し幅が広 い. 長さは幅の約 2.5 倍. 前縁脈指数は 0.6 . 前縁脈の 各区分で， 1 注 $2+3$ とほぼ同じか少し長い，第 3 脈は 前縁脈より太い，第 4 脈汉雄上り強く $\mathrm{S}$ 字状に曲つてい る. 雄より大形で体長 $3.5 \mathrm{~mm}$.

4. Stichillus matsumurai Schmitz, 1952 (図 6)

$$
\text { オオクロノミバエ（新称） }
$$

本種は Schmitz (1952) の報告でも採集地は北海道札 幌であるが，著者らも，札幌と杤木県日光の戦場原で 雄雌多数を得た. Schmitz の新種報告では雄は不明であ つたので，本種の雄に関する記載はこれが最初である。

雄：頭は大きく幅が広い，額は漆黒で棘毛は太く頑 強. 触角は火焰状で先端上り触角刺毛を生ずる. 触角は 茶色で微毛を有する，触鬚は黄色で先端から生ずる剛毛 は極めて長く, 他の剛毛の約 2.5 倍. 胸は黒色で中胸側 板は大きく，上半部に瀻毛を有する．小楯板は幅が長さ の約 2 倍で方形． 2 対の剛毛を有するが，内側のもの泣 極めて長大であり，外側のものは細く短かい，腹部背板 も漆黑であり，第 1 背板の後縁は直線状である. 第 2 背 板は非常に幅広く後縁は後方に突出して弓形を呈する.

第 3 背板も第 2 背板上り泫るく突出している. 第 4 ，第 5 背板も後縁が真直ぐでない，第 2 から第 5 まで横で互 いに重なつている. 第 1 脚の脛節と跗節は黄色. 脛節の 背部中央より少し上に単剛毛を有する．跗節の末節は長 さと幅がほぼ等しい，第 2 脚注黑色である，脛節の中央 に 1 対の剛毛を有する. 第 3 脚腿節は非常に大きく, 脛 節には前面中央に 1 本の独立剛毛を有する。翅注黄灰 色. 基根部謈色. 第 3 脈は分岐せず， 10 数本の繊細 な毛を有する. 平均棍は黒色, 体舆は 3 4 $4 \mathrm{~mm}$.

雌 : 頭部は雄と同様. 触角の第 3 節は雄より小さく丸 く, 黄褐色で, 微毛は少ない。触角刺毛は雄より長い。 触鬚は黄色で下部側縁から剛毛を生ずる．胸部抽よび腹 部背板は雄上ほぼ同様. 翅は雄より大きく, 色は黄色味 が強い. 第 7 脈は弱く不明瞭. 体長 $3.5 \sim 4.5 \mathrm{~mm}$.

5. Conicera (Tritoconicera) breviciliata Schmitz, 1926 (困 7) チビグロノミバエ（新称）

雄: 黑色の小型種である. 額汢黑色で第 1 眼縁棘毛は 単眼前棘毛に近接して生じ，少し短か、，第 3 眼秝毛は 著しく短かくかつ弱い，触角の第 3 節は火焰状で長さは
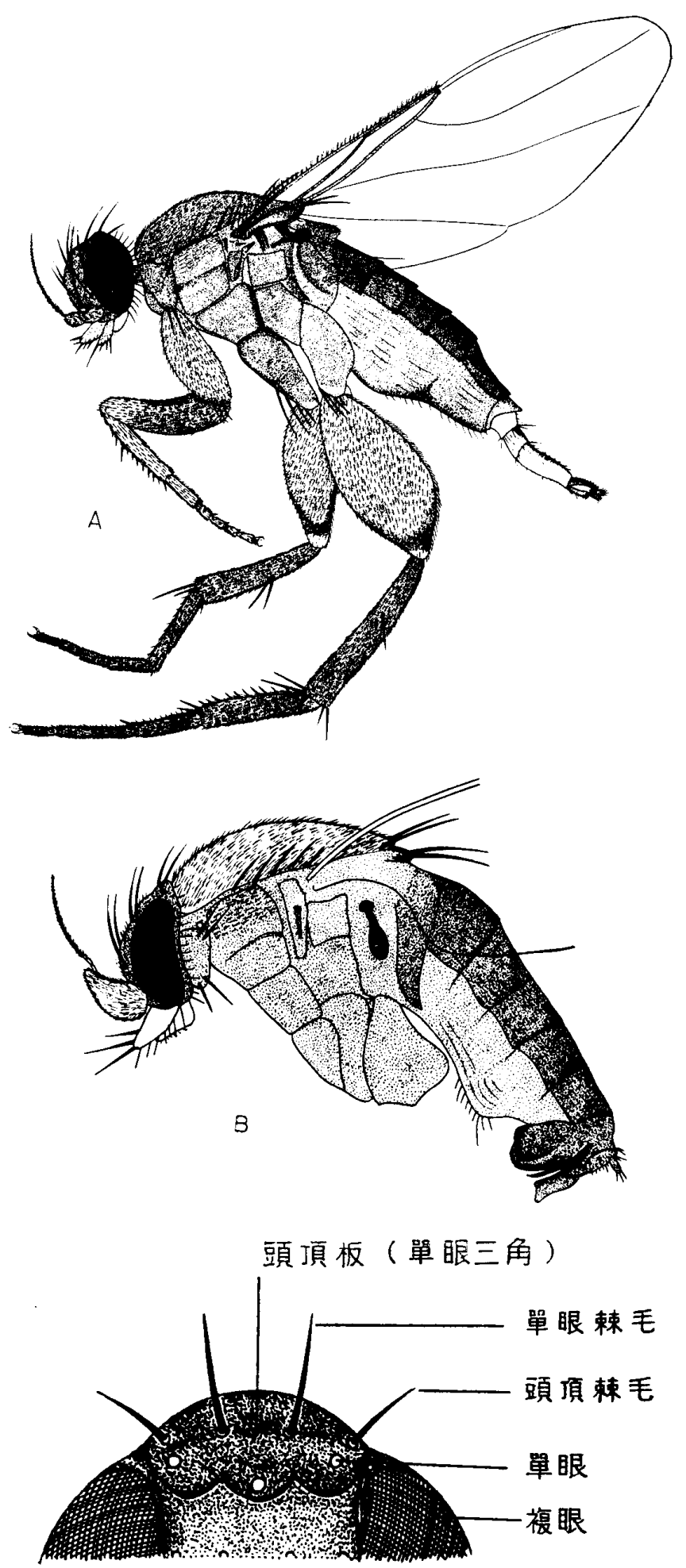

C

図 6 Stichillus matsumurai Schmitz A. 雌； B. 雄； C. 頭部前面上半部 （第 3 翅脈の小棘毛は翅の上面に列生する)

下半部の幅の約 2 倍である. 触䰅は黒色で稀に褐色. 触 角第 3 節の長さの約 $1 / 2$ で紡鍾型を呈し，わずかの短剛 
毛を有する，胸は黒く，多少灰色を带びる，中胸側板は 微毛を有しない，腹部は通常漆黑色. 背板はビロード様 の黒色で，目立たない微毛を有する. 第 2 , 第 6 背板は 長い，腿節は灰黒色で特に第 2 脚腿節には細長い感覚を つかさどると考えられる小窩があり，そこから管棘を生 ずる (図7C)，第 3 脚の腿節は幅の 3 倍以上の長さを有 する，翅は弱い黄色で長さは幅の約 2 倍（1.323×0.63 $\mathrm{mm})$. 前縁脈指数は 0.4. 前縁脈の区分は $8: 3$ であり, 繊毛は短加、第 3 脈は分岐しない。平均棍は黒色. 体 長 $1.1 \mathrm{~mm} \sim 1.46 \mathrm{~mm}$.

雌 : 額は長さより幅がいくらか広い，第 1 眼縁棘毛は 単眼前棘毛より離れている. 触角上棘毛はすより長い. これら頭部の棘毛は横に同間隔，垂直線上にありこれも 等間隔である，触角は小さく丸味がある，触髹は褐色で 雄と同大かまたはそれより小さい。しかしいくらか長い 剛毛を有する．胸背は黒色で密集した毛を有する，中胸 側板も黒く裸出する.腹部は暗色で，背部キチン板は雄

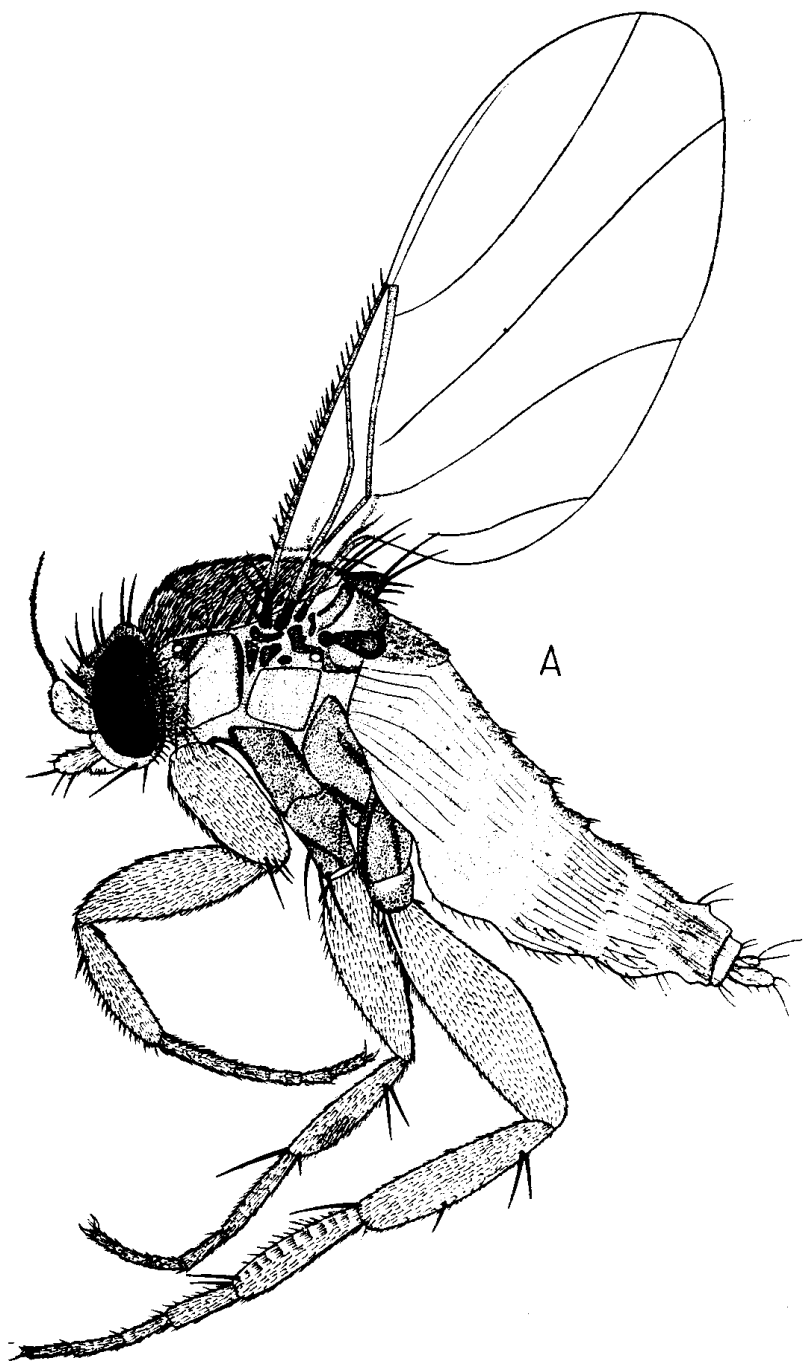

より小さい，第 6 背板は二等辺三角形を呈する. 翅は雄 より長く，いくぶん細い $(1.52 \mathrm{~mm} \times 0.66 \mathrm{~mm})$. 前縁脈 は雄より長く指数は $0.46 \sim 0.47$ で前縁脈の区分は大体 2:1である。繊毛は短か子、背側にある繊毛は第 1 脈 と前縁脈の結合点で終る。第 3 脈は前縁脈より少し太 い. 第 7 脈は翅の縁まで完全にとどく．体長は一般に $1.5 \mathrm{~mm}$.

6. Megaselia (Aphiochaeta) spiracularis Schmitz, 1938 (困 8) オオキモンノミバエ(新称)

雄: 額は長さより幅が広く, 亜長方形. 触角上棘毛は 2 奶で前下方に彎曲している。触角は普通の大きさで, 下半部は赤褐色で上部は暗色. 触角刺毛は非常に密生し た繊毛を有する。触鬚は黄色で末端に短棘毛を列生す る，吻は 5 対の偽気管を有し，雌は特に良く発達してい る.胸部は黄褐色または暗色. 小楯板には 4 剛毛あり, 中胸側板と翅側板は黄暗色で中胸側板の上半部に同長の
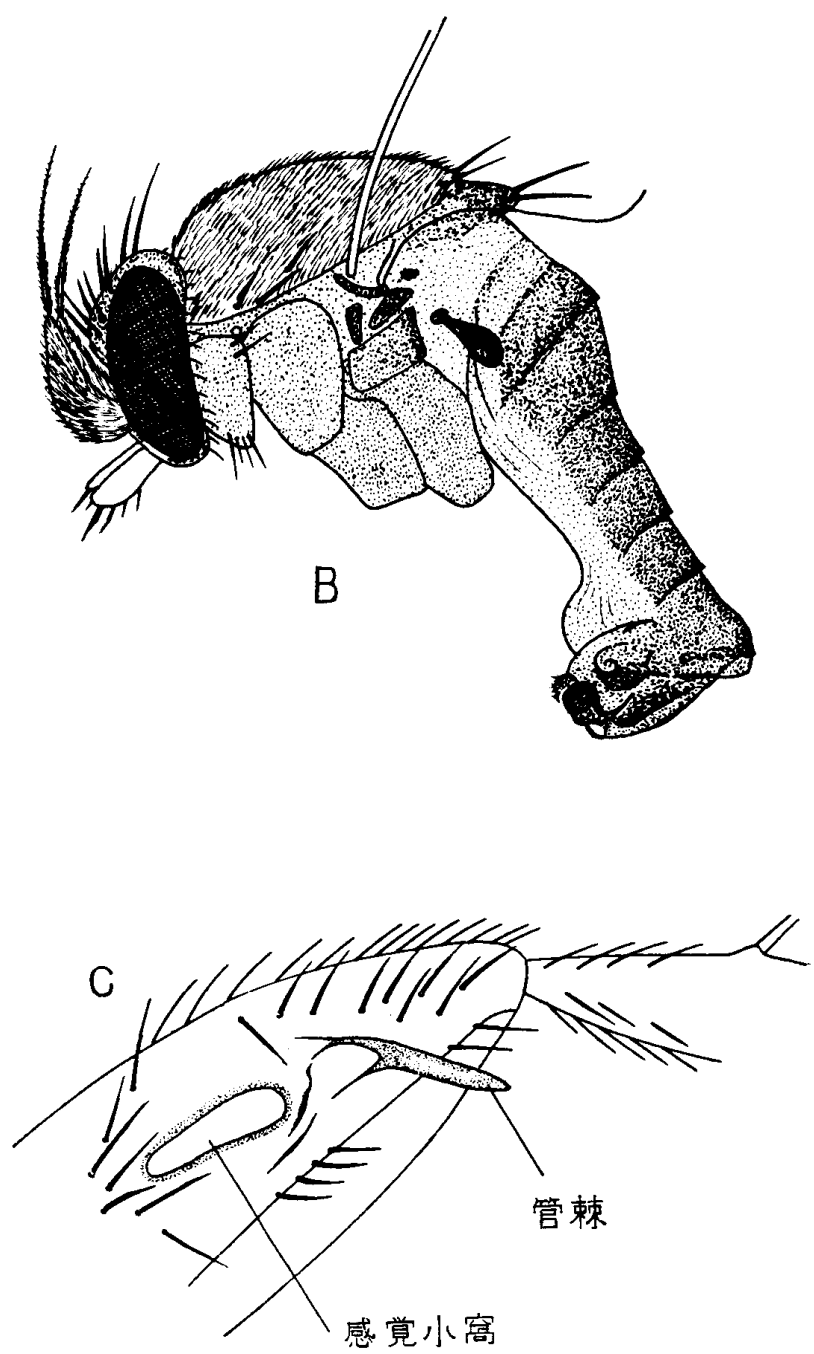

図 7 Conicera (Tritoconicera) breviciliata Schmitz
A. 雌; B. 雄
C. 第 2 脚腿節 ( 
短毛を有する，稀には弱い別な単岡毛を有することもあ る. 腹部は黄色. 第 1 背板から第 5 背板までは大きく横 面までかぶさつている，第 2 背板と第 6 背板に長い毛を 有する，気門は大きいが第 2 腹節の気門は他の節の気門 より小さい. ヨーロッパ麾の Megaselia stigmatica \& 気門が大きく良く似ているが，M. stigmatica は第 2 節 から第 6 節迄順に気門が大きくなつているのに反し，本 種では第 2 節のものの他は同大である．第 3 脚腿節は幅 広く，先端に黑斑がある．腹面の稜の基部 $1 / 3$ に 6 8 本 のやや長い毛を有する。第 3 脚脛節は均一に分散した 9 10 本の丈夫な発達した後背剛毛を有する。翅はほ之 えど透明で前縁脈指数は約 0.48 . 前縁脈繊毛は短かく, (0.07〜0.08mm) 前粶脈の区分は不定であるが大体 4 ：
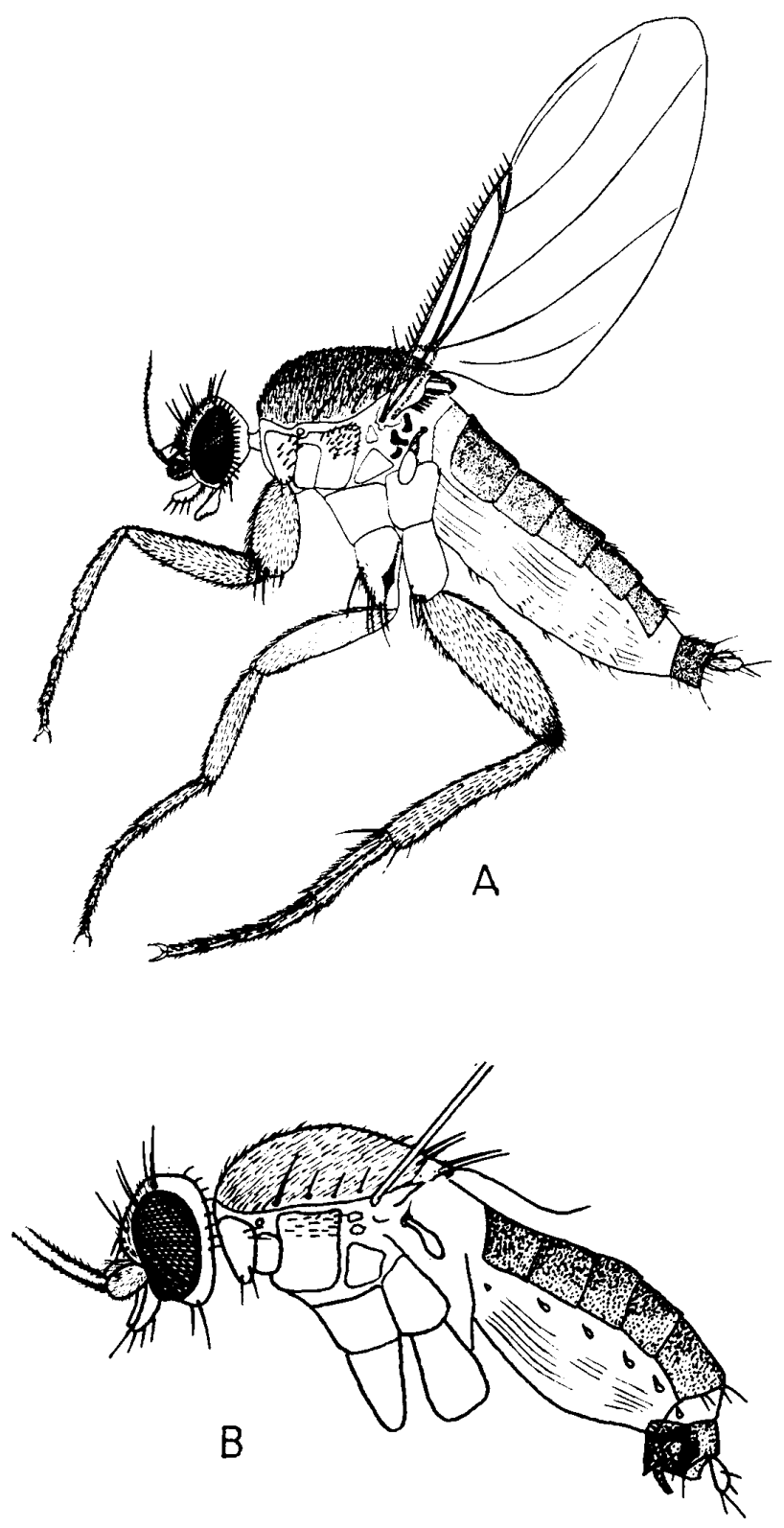

図 8 Megaselia (Aphiochaeta) spiracularis Schmitz A. 此; B. 雄
$3: 1$ である. $\mathrm{m}_{1}$ 湔方に凹彎している。平均棍は黄色 体長は $1.1 \sim 1.9 \mathrm{~mm}$.

雌 : 雄の特徵と大体同じであるが著しく異なる点は, 腹部の気門が非常に小さいことである，額は常に明るく 赤黄色または黄色である，触角はいくらか小さい，胸部 は翅側板のみいくらか暗色. 小楯板剛毛は 4 本. 第2 背 板の前部は幅広く，後縁は狭くなつている。第 3 背板以 下は漸次幅が狭くなつている，第 1 背板は細長く弱い. 第 6 背板は 2 つに分かれた茶褐色の斑紋としてみられ る. 前縁脈指数は 0.51 までで, 前縁脈の区分は 4.7 : $3: 1$. 体長注 $2.2 \mathrm{~mm}$ 迄.

\section{総括}

現在までに採集しかつ同定し得た日本産ノミバエ科の 八エは 5 属 6 種であり，これらを罒をそえて記載した。 これらの種名注次に示すごとくである。

1. Diploneura (Dohrniphora) cornuta (Bigot, 1857)

2. Diploneura (Diploneura) peregrina(Wiedemann, 1830)

3. Aneurina unispinosa (Zetterstedt, 1860)

4. Stichillus matsumurai Schmitz, 1952

5. Conicera (Tritoconicera) breviciliata Schmitz, 1926

6. Megaselia (Aphiochaeta) spiracularis Schmitz, 1938

以上のなかで Stichillus matsumurai の雌は Schmitz (1952)にによる新種であるが，本種の雄はこれが最初の 記載である。 また北海道で採集された Aneurina unispinosa は日本末記録種であつた. 他の 4 種のうち Diploneura cornuta Ł Megaselia spiracularis はわが国の 最も普通な種類であり，また Diploneura peregrina おう よび Conicera breviciliata は東京付近での普通種であ る.さらにノミバェ科の亜科と重要属の検索表を合わせ 揭げた.

\section{文献}

1) Bohart, G. E. (1947): The phorid flies of Guam. Proc. of United States Nat. Mus., 96 (3205) : 397-416. -2) Brues, C. T. (1911): The Phoridae of Formosa. Annal. Musei Nationalis Hungarici, 9: 530-559. -3) Brues, C. T. (1914): A synonymic catalogus of the dipterous Family Phoridae. Bull. of Wisconsin Nat. Hist. Soc., 12 (3-4) : 85-152. 4) Brues, C. T. (1924): Additions to the Phoridae of Formosa. Psyche, 31 (5) : 206-223. -5) Brues, C. T. (1936) : Philippine Phoridae from the Mount Appo region in Mindanao. Proc. of Amer. Acad. 
of Arts \& Sci., 70 (9) : 365-466. -6) Brues, C. T. (1944): New Neotropical Phoridae. Psyche, 51 (3-4) : 151-161. -7) Matsumura, S. (1915)：昆虫 分類学, 下巻, p. 17, 警醒社書店, 東京. 一8) Matsumura, S. (1916)：新日本千虫図解, 2 巻 : 377378 , 整醒社書店, 東京. -9) Kinoshita, S. (1918)： 無翅蛋䖵の一新種に就をて. 動雑, (360)：402-408. -10) Paterson, H. E. (1959): A new species of the Genus Puliciphora Dahl (Diptera: Phoridae). Rev. Ecuat. Ent. Par., 1(3) : 61-67. -11) Sasaki, C. (1935): On a new Phorid fly infesting our edible mushroom. Proc. Imp. Acad. Japan, 11: 112. -12) Schmitz, H. (1938-1956): Die Fliegen der Palaearktischen Region. 33. Phoridae : 1-512. -13) Shiraki, T. (1932)：日本昆虫図鑑：111, 北隆館, 東 京. -14) Shiraki, T. (1955) : Classification of insects : 702-704, Hokuryukan, Tokyo. -15) Shiraki, T. (1958): Sanitary insects : 786-791, Hokuryukan, Tokyo.

\section{Summary}

Descriptions of six species of phorid flies belonging to five genera are given in the present paper.
These species are as follows:

1. Diploneura (Dohrniphora) cornuta (Bigot, 1857)

2. Diploneura (Diploneura) peregrina (Wiedemann, 1830)

3. Aneurina unispinosa (Zetterstedt, 1860)

4. Stichillus matsumurai Schmitz, 1952

5. Conicera (Tritoconicera) breviciliata Schmitz, 1926

6. Megaselia (Aphiochaeta) spiracularis Schmitz, 1938

Of these, the male of Stichillus matsumurai was described for the first time by the authors, although the female had been described by Schmitz previously. Aneurina unispinosa was found in Hokkaido for the first time in Japan. Diploneura cornuta and Megaselia spiracularis are very common species in Japan, and Diploneura peregrina and Conicera breviciliata are commonly found in Tokyo. Keys to subfamilies and important genera of Phoridae are also given in this paper.

\title{
ある民家で観察したイエバエ成虫の \\ 出入りについて1)
}

\section{Observation on the entrance and exit of house flies in a residence}

\author{
緒 方 一 喜2) \\ Kazuki Ogata
}

筆者ら (1960 a,b) は，さきに，イエバェ，ヒメイ エバェの多数個体にマーキングを施し，広地域における 分散飛翔の模様を調べた. その結果, 予想外にその活動 範囲は狭いことを知つたが，この調查は広い地域におけ る大ざつぱな分散を知るに止まつた。

1）八エの行動に関する研究 第 5 報

Studies on the behavior of public health important flies, V

2) 国立予防衛生研究所浯生昆虫部

Department of Medical Entomology, National Institute of Health, Tokyo
今回報告するものは，ある一軒の家で生活している1 エバエ個体群の中でどのような巽動があるものかを観察 したものである.この知見は，前報よりもさらに細かく イエバエ個体の行動を追跡したもので, 実用的には, 残 留噴霧方式などの成虫対策を構ずる上に参考資料を与え るものと考える.

場所は，横浜市戸塚区瀬谷町にある一民家. 立地的に は, 郊外住宅地で, 住宅と田畑, 雑木林が混在している 地域である. 観察を行つた期間は，1959 年 9 月 11 日か ら10月8日まで. 